\title{
Green space water use and its impact on water resources in the capital region of China
}

\author{
Xuanchang Zhang ${ }^{a}$, Feng Mi ${ }^{\text {a, }{ }^{*}, \text { Nan Lu }}{ }^{b}$, Nana Yan ${ }^{c}$, Lenka Kuglerova ${ }^{\mathrm{d}}$, Shibao Yuan ${ }^{\mathrm{e}}$, \\ Qiang Peng ${ }^{\mathrm{e}}$, Oliver Zheyi Ma ${ }^{\mathrm{f}}$ \\ a School of Economics and Management, Beijing Forestry University, 35 Qinghua East Rd, Haidian District, Beijing, 100083, China \\ b State Key Laboratory of Urban and Regional Ecology, Research Center for Eco-Environmental Science, Chinese Academy of Sciences, 18 Shuangqing Rd, \\ Haidian District, Beijing, 100085, China \\ ${ }^{c}$ Institute of Remote Sensing and Digital Earth, Chinese Academy of Sciences, West Beichen Road, Chaoyang District, Beijing, 100101, China \\ ${ }^{\mathrm{d}}$ Department of Forest and Conservation Sciences, University of British Columbia, Vancouver, BC V6T 1Z4, Canada \\ e Afforestation Office, Beijing Gardening and Greening Bureau, 1 Xiaohuangzhuang North St, Dongcheng District, Beijing, 100013, China \\ ${ }^{\mathrm{f}}$ Vancouver School of Economics, The University of British Columbia, Vancouver, BC V6T 2E8, Canada
}

\section{A R T I C L E I N F O}

\section{Article history:}

Received 29 November 2016

Received in revised form

18 January 2017

Accepted 9 February 2017

Available online 24 February 2017

\section{Keywords:}

Urban green space

Water resource

Evapotranspiration

Water balance

ETWatch

\begin{abstract}
A B S T R A C T
Green space plays important roles in the environment as an integral part of the urban ecosystem. It may have various impacts on urban water resources depending on its location and type. Beijing is a major city that is severely deficient in water resources and the conflicts of water demand between different users such as industry, farm, residence, orchard, etc., becoming increasingly evident. Thus rational water utilization within the green space is critical to regional water security. Based on remote sensing, field investigation, and statistical data, this study focuses on the water use and the impacts of three types of green space (i.e., mountainous vegetation, suburban farmland, and green gardens) on water resources in the capital region of China from 2002 to 2013 . The results show that the mean annual evapotranspiration (ET) was around $600 \mathrm{~mm}$ for the mountainous vegetation, which is almost equal to precipitation (P) in normal years. However, in the years with elevated rainfall, the mountainous vegetation distributing in catchment region contributed water to the reservoirs. In contrast, suburban farmland and green gardens were both dependent on groundwater for irrigation, with the rainfall utilization rate being low, which caused negative effects on water resources. The inefficient irrigation of suburban farmland was up to $115 \mathrm{~mm}$ and the suburban farmland area with higher water consumption was $230 \mathrm{~km}^{2}$ in 2005 (out of the total $50 \%$ suburban farmland). ET of the green gardens was relatively low $(400 \mathrm{~mm}$ ) compared to the mountainous vegetation. P (525 mm) could meet the demand of ET, and consequently, irrigation (as high as $581.95 \mathrm{~mm} / \mathrm{m}^{2}$ ) was actually superfluous. Our results suggest that an integrated water management scheme is needed for the green space, this includes improving irrigation efficiency and increasing infiltration rate of rainfall in urban land surface.
\end{abstract}

() 2017 Elsevier Ltd. All rights reserved.

\section{Introduction}

Urban green space is a network system, which consists of green gardens, urban forests, suburban farmland and water (Xu et al., 2011; Diane et al., 2011; Lee and Maheswaran, 2011; Wolch et al., 2014). The green space has the functions of e.g., air purification, carbon sequestration, and recreation (Kong et al., 2010; Xu et al.,

\footnotetext{
* Corresponding author.

E-mail addresses: xuanchang9989@163.com (X. Zhang), mifengsun@163.com (F. Mi), nanlv@rcees.ac.cn (N. Lu), yannn@irsa.ac.cn (N. Yan), lenka.kuglerova@ gmail.com (L. Kuglerova), yuany@bjfb.gov.cn (S. Yuan), panchoo@qq.com (Q. Peng), oliver.zheyi.ma@gmail.com (O.Z. Ma).
}

2011; Colding and Barthel, 2013; Zhang et al., 2012a,b; Yang et al., 2015), while also having great impacts on water resources by regulating the distribution of evapotranspiration (ET) and consequently water yield (WY) (Bosch and Hewlett, 1982; Farley et al., 2005; Lu et al., 2011). The impacts of urban green space on water resources have been concerned broadly because the different types of green space may play different roles in water resource dynamics under various environmental conditions (Xia et al., 2007; Coutts et al., 2012; Yang et al., 2015).

Many cities in the world have constructed specific water management systems for urban green space according to climate, terrain and green space development plans. For example, in order 
to decrease urban flood risk and reduce irrigation water, Boston and Minneapolis (USA) have explored the water management of urban green space since 1900s (Welch, 1993). They established an urban park system along rivers in the cities, which strengthened regulation of surface runoff and decreased the dependence on ground water for green space (Brown et al., 2013; Dobbie et al., 2014). In contrast in London and Tees Valley of Britain (UK), the scattered distribution of green space caused lower irrigation efficiency and high water waste. The theory of Green Infrastructure (GI) is building a unified management mechanism through the construction of green space network, which can connect the sporadic small green gardens and farmland by the greenways effectively (Tzoulas et al., 2007; Gill and Handley, 2007). In Melbourne and Sydney (Australia), the theory of Water Sensitive Urban Design (WSUD) has been put forward that a complete rain water recovery and reuse system should be established which increased rainfall utilization and reduced groundwater consumption (Wong, 2007; Coutts et al., 2012).

Water resources management of green space have been focused in China during the past twenty years (Xia et al., 2007; Byomkesh et al., 2012; Barthel and Isendahl, 2013). Despite many policies about water management for urban green space being implemented, problems of water shortage and water waste are still not solved because they only focused on single issue. For example, the ability of water supplement to the reservoirs has gradually declined with the changes of land use type (e.g., the unreasonable expand of forests and grassland), which caused substantial decrease of available water (Huang et al., 2012; Li et al., 2015). Insufficient utilization of rainwater and extensive irrigation still exists in farmland and green gardens causing water use deficiencies.

Beijing, as the capital of China, is a region with serious water shortage. The water resources per capita of Beijing are less than $100 \mathrm{~m}^{3}$, which was far below the average level of China and well below the internationally recognized limit of $1000 \mathrm{~m}^{3}$ (Huang et al.,
2012; Wang et al., 2013; Fan et al., 2015). The demand for green space is increasing with the urban development and environment deterioration. At the end of 2014, the green space area was $10359.1 \mathrm{~km}^{2}$ was about $63.12 \%$ of total area of Beijing. According to the requirements of urban green space developing in "the Urban Master Plan for Beijing (2004-2020)", green space in Beijing will grow at a faster rate in coming years. However, the water stress may be intensified with the contradictions between water scarcity and urban green space development (Xu et al., 2011). Therefore, it is critical to quantify the water use of the green space and identify the potential issues.

Good understanding of the interactions between climate, landform, type, and spatial distribution of the green space is the basis for making an appropriate water management scheme. Therefore, the objective of this study is to assess the impacts of green space on the water resources of the Beijing region, focusing on three types of green space including mountainous vegetation, suburban farmland, and green gardens. Specifically, we aim to 1) examine the spatial and temporal variation of ET and WY from 2002 to 2013 as well as the hydrological consequences of the three types of green space; and 2) evaluate the irrigation efficiency for farmland and green gardens. We also expect to provide useful management advice to local government on green space water management.

\section{Material and methods}

\subsection{Study area}

Beijing $\left(39^{\circ} 26^{\prime}-41^{\circ} 03^{\prime} \mathrm{N}, 115^{\circ} 25^{\prime}-117^{\circ} 30^{\prime} \mathrm{E}\right)$ is located at the border of the North China Plain and Inner Mongolia (Fig. 1a), and the total area is $16411 \mathrm{~km}^{2}$ (Xie et al., 2017). The Taihang mountain chain is located in the west and the Yanshan mountain chain located in the north, while the elevation is below $100 \mathrm{~m}$ above sea

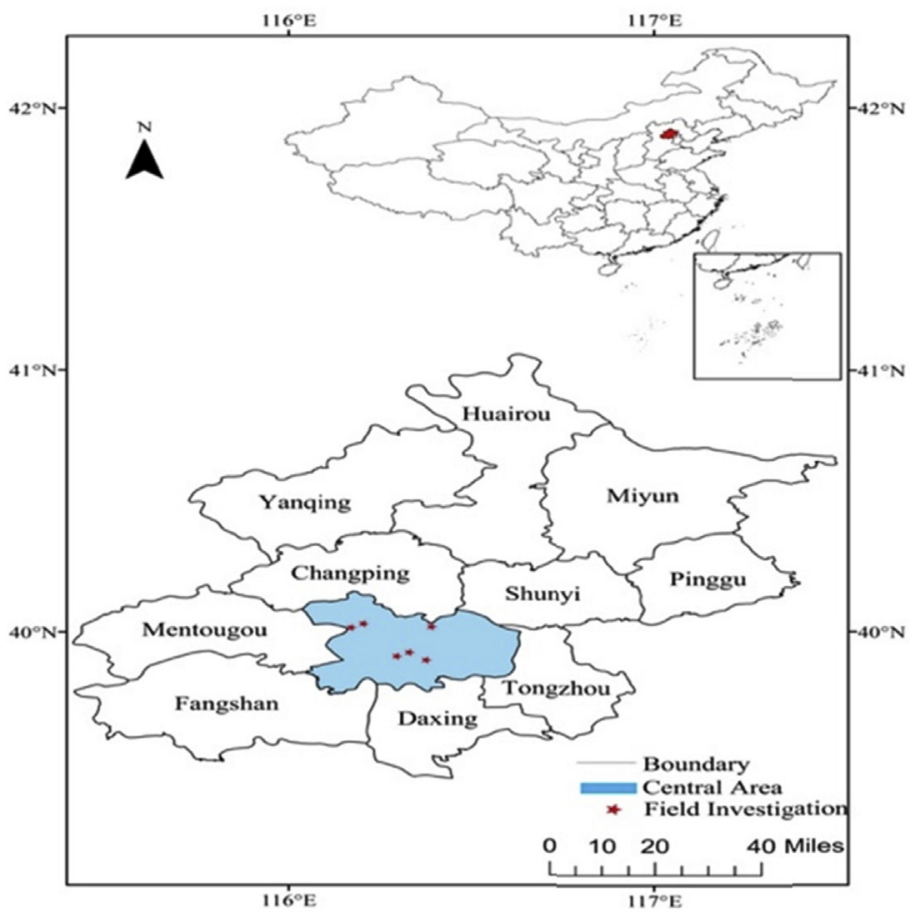

(a)

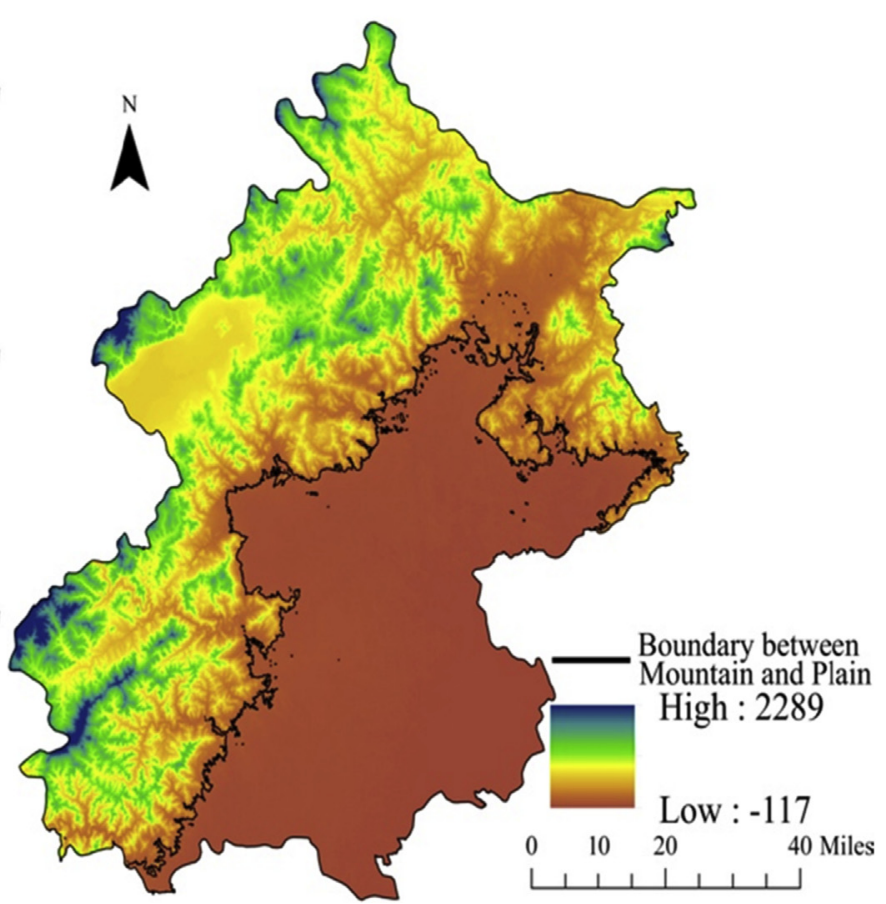

(b)

Fig. 1. Location of the study area (a); The DEM of Beijing (b). 


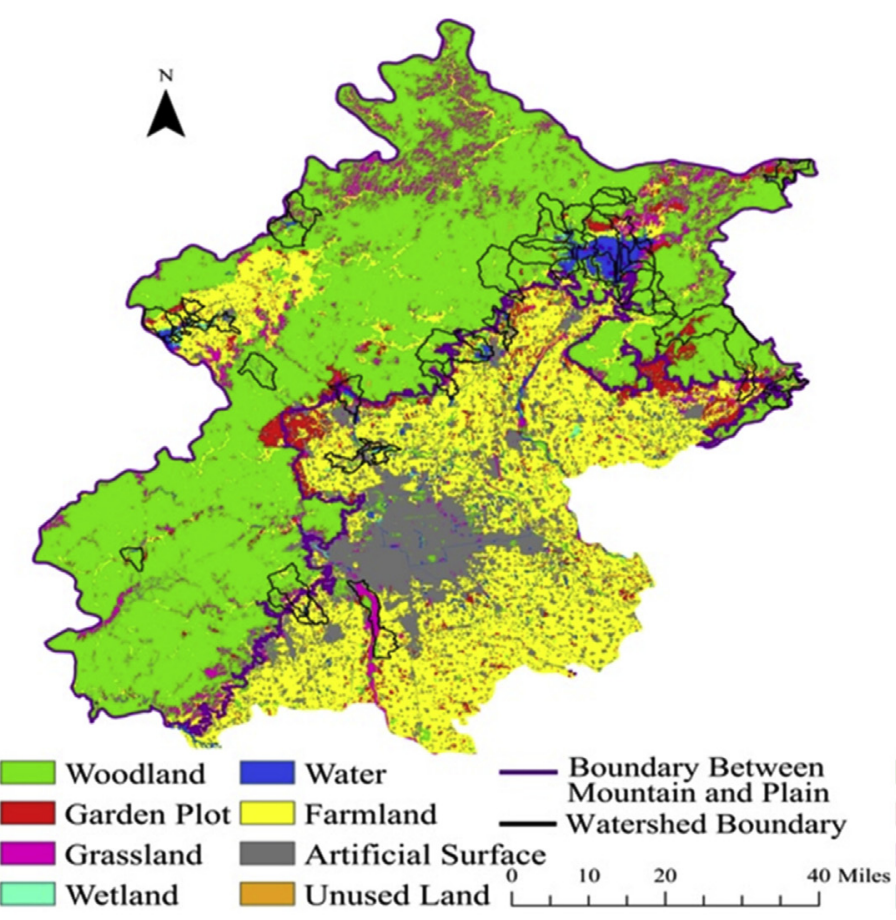

(a)

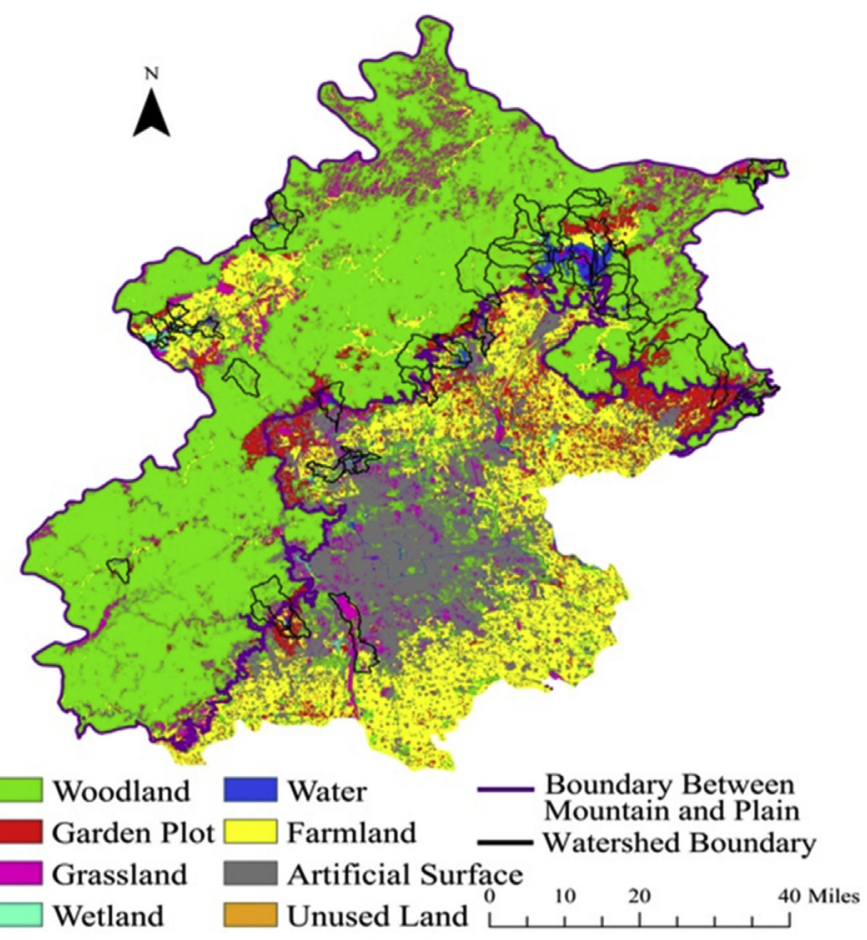

(b)

Fig. 2. Land use/cover distributions of Beijing in 2000 (a) and 2010 (b).

level in the southeast, which forms the topographic features on three sides in Beijing (Fig. 1b). Beijing's climate is typically warmtemperate continental monsoon climate (Huang et al., 2012; Xie et al., 2017). The yearly average temperature is $10{ }^{\circ} \mathrm{C}-12^{\circ} \mathrm{C}$ and average annual $\mathrm{P}$ is $585 \mathrm{~mm}$, July to September is the main growing season.

\subsection{Methods}

\subsubsection{Classification of Beijing's green space}

The spatial distribution of urban green space is affected by topography. With assistance from GIS, we dealt with DEM (digital elevation model) data to analyze the terrain features of regions and distinguished mountains and plains with the dividing line of $100 \mathrm{~m}$ (Fig. 1b). Additionally, from the overlapping maps of land use/ coverage (Fig. 2) and landform, we divided Beijing's green space into mountainous vegetation, suburban farmland, and green gardens. The mountainous vegetation mainly includes woodland and grassland located in the mountain area, and the main vegetation types are coniferous forests, broadleaf forests, shrubs and herbs. The green gardens consist of woodland and grassland distributing the plain area, and the plain farmland forms the suburban farmland. Deciduous trees, evergreen trees and some perennial plants form the green gardens, wheat, corn, cotton and soybean are widely distributed in the farmland (Wang et al., 2008; Zhang et al., 2013).

The vegetation cover of remote-sensing inversion bears high level of consistency with statistical data (Fig. 3). The vegetation cover was $53 \%$ in the official announcement and $56.45 \%$ in remotesensing inversion, which had a relative error of $3.45 \%$. The inversions in 7 counties were almost completely consistent with the official data. The vegetation cover was slightly underestimated due to the street trees, because small green spaces cannot be distinguished in the $30 \mathrm{~m}$ precision remote-sensing image. However, the study objective was the larger green spaces, the remote-sensing inversion meets the research requirements.

\subsubsection{Water balance approach}

The water balance equation was used to evaluate the water use of the green space:

$\mathrm{WY}=\mathrm{P}-\mathrm{ET}$

Where: WY is mean annual water yield $(\mathrm{mm})$; $\mathrm{P}$ is mean annual precipitation $(\mathrm{mm})$; ET is mean annual evapotranspiration $(\mathrm{mm})$. When $\mathrm{WY}>0$, it indicates that the P can meet the demand of ET, thus water would be at a surplus, and vice versa (Lu et al., 2011).

The study analyzed the spatial distribution of water balance of green space by superposition analytical method and spatial statistics analysis in GIS. Meanwhile, we used the stacking analysis of GIS to obtain the ET and P data, then adopted different methods to

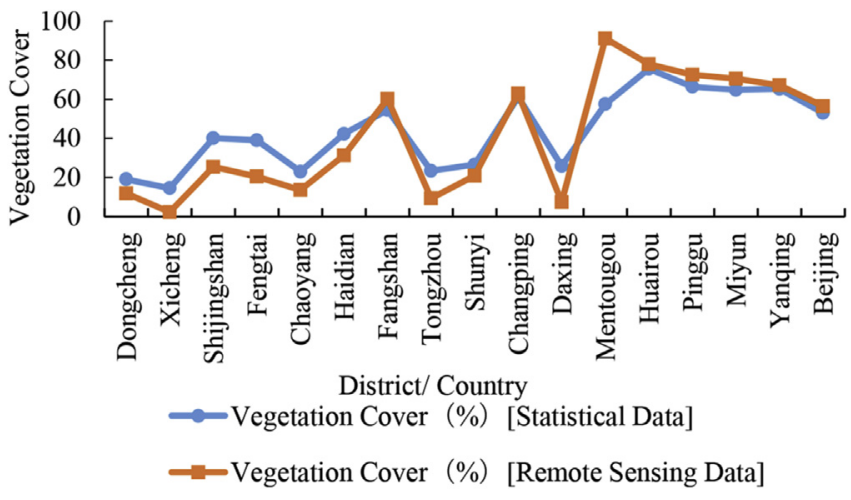

Fig. 3. Validation of vegetation cover of remote-sensing inversion. 
study the dynamic changes of water balance in green space. The specific are as follows:

(1) Mountainous vegetation (without irrigation). Affected by terrain factors, the mountainous vegetation can produce surface runoff contributing to the reservoirs distributing in catchment region. To study the issue of water supplement from mountainous small watershed, we analyzed the replenishing contribution rate of mountainous vegetation in the catchment. With the help of GIS, we divided the watersheds draining into large and medium reservoirs by hydrological analysis of the DEM data and the vector data of rivers and reservoirs (Fig. 2). The formula of replenishing contribution rate is as follows:

$\mathrm{CR}=\frac{\mathrm{WY} \times \mathrm{WA}}{\mathrm{WI}}$

Where: CR is the contribution rate; WY is the water yield ( $\mathrm{m})$; WI is the total water inflow of reservoirs $\left(\mathrm{m}^{3}\right)$; and WA is the areas of catchment $\left(\mathrm{m}^{2}\right)$. When $\mathrm{WY}>0$, the catchment region can replenish the water to reservoirs. When $\mathrm{WY}<0$, the vegetation uses more water than $\mathrm{P}$, and the catchment region cannot have water contributions to the reservoirs.

(2) Suburban farmland and green gardens (with irrigation). Based on the analysis of the water balance variation from 2002 to 2013 , this study analyzed the ineffective irrigation problem for suburban farmland and green gardens by comparing the difference between the amount of water demand (WD) and actual irrigation (AI). The water demand (WD) was the difference between ET and P (ET - P), which represents the best irrigation strategy. When, $\mathrm{WY}>0, \mathrm{P}$ can meet the vegetation water use and does not need irrigation $(W D=0)$, the irrigation would be inefficient if $\mathrm{AI}>0$. When $\mathrm{WY}<0, \mathrm{P}$ is not adequate for actual ET and the irrigation is necessary (WD $>0$ ). The irrigation was efficient if $\mathrm{WD} \geq \mathrm{AI}$, otherwise it would be inefficient. The formula of $\mathrm{AI}$ is as follows:

$\mathrm{AI}=\frac{\mathrm{TI}}{\mathrm{CA}}$

Where: $\mathrm{AI}$ is the unit area of the actual amount of irrigation $\left(\mathrm{m}^{3}\right)$; TI is the total irrigation $\left(\mathrm{m}^{3}\right)$; $\mathrm{CA}$ is the areas that are the study objective $\left(\mathrm{m}^{2}\right)$

\subsection{Data and information sources}

The land use/cover data (resolution: $30 \mathrm{~m}$ ) in 2000 and 2010 used in this study were derived from the research results of the Chinese Ten Years Eco-Environment Remote Sensing Monitoring project, which had classification system following IPCC and LCCS. Annual actual ET (soil evaporation, water surface evaporation and plant transpiration) for Beijing from 2002 to 2013 (resolution: $1 \mathrm{~km}$ ) and annual actual ET for the five counties in 2005 and 2006 (Daxing, Pinggu, Miyun, Tongzhou, Fangshan; resolution: $30 \mathrm{~m}$ ) were obtained from ETWatch. ETWatch is an integration of the "Residual Approach (the energy balance model)" and PenmanMonteith model. SEBAL (Surface Energy Balance Algorithm for Land) and SEBS (Surface Energy Balance System) were used to estimate ET under clear-sky conditions, while Penman-Monteith model was used to calculate daily ET with the input of daily surface resistance, which was estimated using temporal reconstruction method (Xiong et al., 2008). The ETwatch model required many sites in the process of calculating the higher resolution data, and we only obtained the site data in the five districts/countries from 2005 and 2006. Therefore, we used ETwatch data of two different spatial resolutions for our analyses. The resolution $(30 \mathrm{~m}$ and $1 \mathrm{~km}$ ) of ET data has verified in Hai Basin using by the monitoring data, which can meet the study requirement (Wu et al., 2008, 2012). Climate data (resolution: $1 \mathrm{~km}$ ) from 2002 to 2013 is from the China Meteorological Administration (http://data.cma.cn/). DEM data (resolution: $30 \mathrm{~m}$ ) is from USGS (https://www.usgs.gov/). The WI data of Beijing's large and medium-scaled reservoirs comes from the Water Resources Bulletin (http://www.bjstats.gov.cn/). Data on the areas of suburban farmland and the TI in 2005 and 2006 originates from Beijing Municipal Bureau of Statistics (http:// www.bjstats.gov.cn/). Data on the areas and irrigation of six urban parks (Olympic Forest Park, Beijing Botanical Garden, Taoranting Park, Beijing Zoo, Zizhuyuan Park, and Xiangshan Park) are derived from field investigation form 2013. In the field investigation, we obtained these data through a questionnaire survey for the greening technologist and an in-depth interview with the park administrator.

\section{Results}

\subsection{The change of green space between 2000 and 2010}

Land use/cover experienced tremendous changes from 2000 to 2010, which mainly took place in central city districts and the ambient areas. Area of woodland, grassland, garden plot, and artificial surfaces increased while farmland and water decreased from 2000 to 2010. Farmland area decreased from $4318.46 \mathrm{~km}^{2}$ to $2823.72 \mathrm{~km}^{2}$, while artificial surfaces increased from $2161.44 \mathrm{~km}^{2}$ to $2941.32 \mathrm{~km}^{2}$, of the growth rate was $36.1 \%$ (Fig. 4). Comparing the area of different green space from 2000 to 2010, we found that mountainous vegetation area has been stable (from $8524.82 \mathrm{~km}^{2}$ to $8579.06 \mathrm{~km}^{2}$ ), while suburban farmland area and green gardens area have dramatic changed. Suburban farmland area decreased from $3561.05 \mathrm{~km}^{2}$ to $2275.60 \mathrm{~km}^{2}$, while green gardens area increased from $381.42 \mathrm{~km}^{2}$ to $802.47 \mathrm{~km}^{2}$, of the growth rate was $110 \%$.

\subsection{Spatial distribution of water balance}

The regional mean annual $\mathrm{P}$ and ET was approximately $544.13 \mathrm{~mm}$ and $543.53 \mathrm{~mm}$, respectively. The spatial distribution of the mean annual $\mathrm{P}(500 \mathrm{~mm}-600 \mathrm{~mm})$ was relatively uniform across the study areas (Fig. 5a). However, the spatial variation of mean annual ET was high. The region of ET $>400 \mathrm{~mm}$ was mainly located in the outer suburban regions and the mountainous areas. The maximum ET occurred in the Miyun reservoir region (ET $>800 \mathrm{~mm})$. The lower ET region $($ ET $<400 \mathrm{~mm}$ ) was located

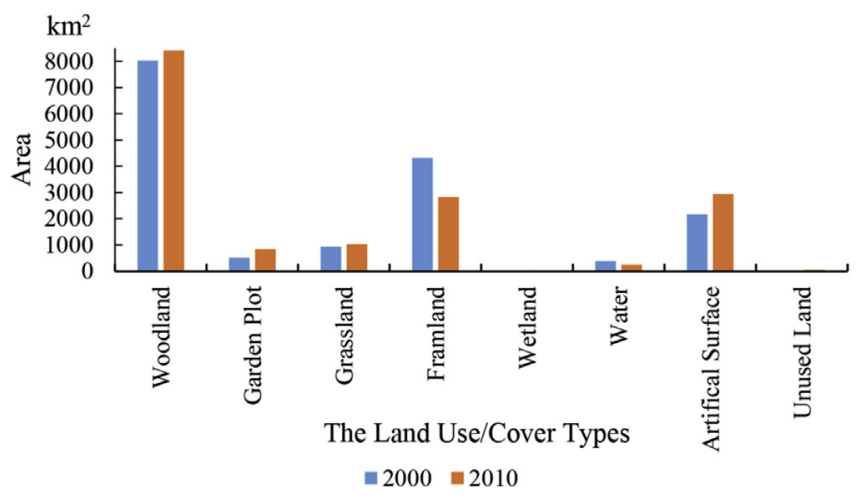

Fig. 4. The area change of land use/cover types. 


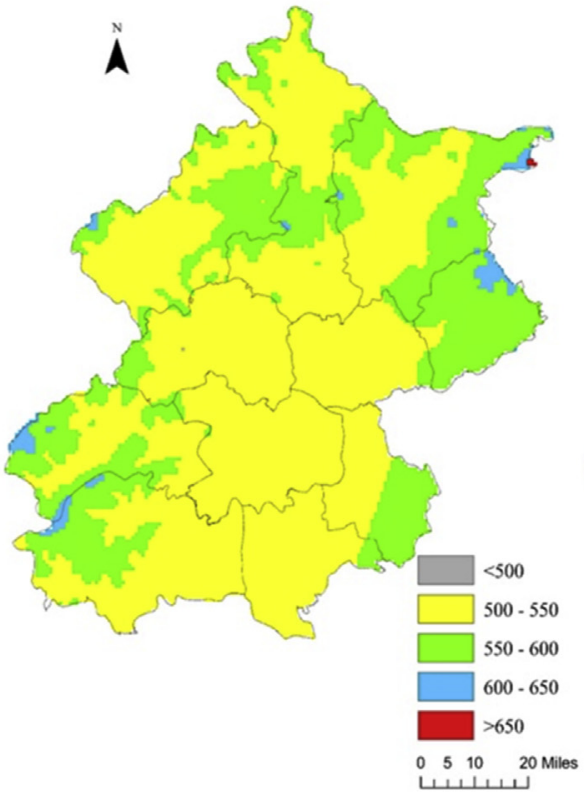

(a)

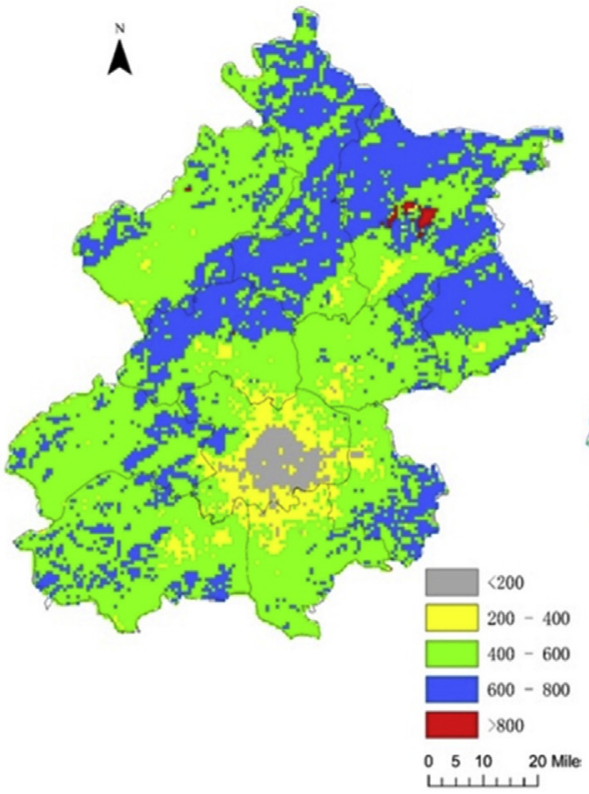

(b)

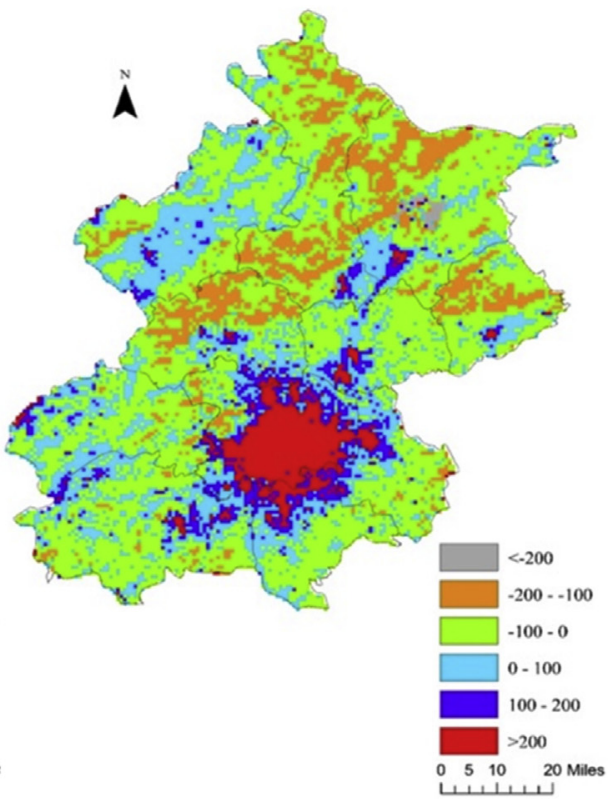

(c)

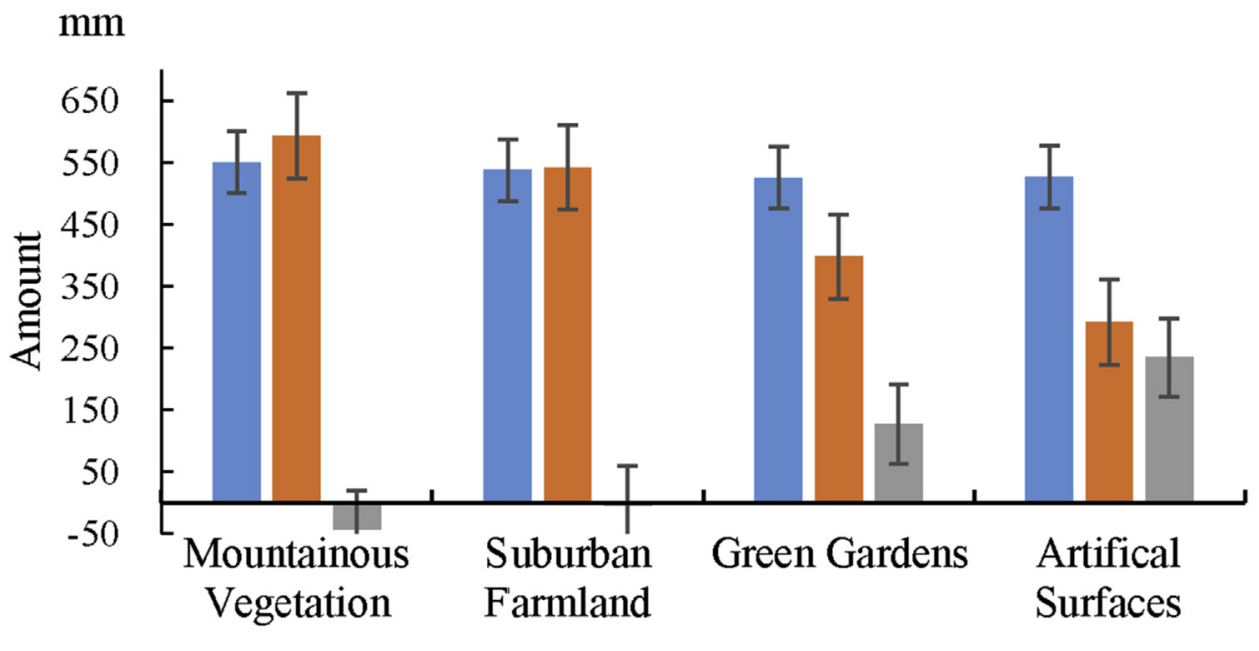

Type of Green Space

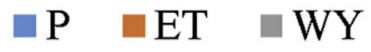

(d)

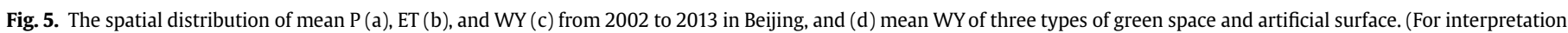
of the references to colour in this figure legend, the reader is referred to the web version of this article.)

principally in the suburban regions and the central city districts, and the minimum values were found in central city districts $($ ET $<200 \mathrm{~mm}$ ) (Fig. 5b). Consequently, the distribution of mean WY showed a distinct spatial pattern. The value of mean WY was generally positive in central city districts and negative in other areas (Fig. 5c).

By comparing the land use/cover map and the spatial distribution of mean WY, it was obvious that green gardens and artificial surface had positive WY. At the same time, WY of the mountainous vegetation was on average $-43.12 \mathrm{~mm}$ (ranging from $-220.28 \mathrm{~mm}$ to $58.61 \mathrm{~mm}$ ), and $\mathrm{WY}$ of the suburban farmland was $-3.89 \mathrm{~mm}$ (ranging from $-103.19 \mathrm{~mm}$ to $13.95 \mathrm{~mm}$ ). P was almost the same for the three types of green space (ranging from $525.15 \mathrm{~mm}$ to $550.38 \mathrm{~mm}$ ). However, they were visibly different in ET with the highest ET in mountainous vegetation $(593.50 \mathrm{~mm})$ and the lowest ET in green gardens $(398.13 \mathrm{~mm})$. Therefore, mountainous vegetation and suburban farmland were water deficient from 2002 to 2013, and green gardens $(127.03 \mathrm{~mm})$ had a water surplus. The 
mean ET $(292.19 \mathrm{~mm})$ in artificial surfaces was lower compared to green space, which caused the mean WY $(234.62 \mathrm{~mm})$ significantly higher than green space, indicating the high precipitation utilizing and water regulating capacity of the green space.

\subsection{The temporal variation of water balance of green space in Beijing}

\subsubsection{Mountainous vegetation}

The annual $\mathrm{P}$ varied from $405.78 \mathrm{~mm}$ to $733.20 \mathrm{~mm}$ in the period from 2002 to 2013 . The mean annual P was $550.38 \mathrm{~mm}$, which was smaller than the long-term mean of this area $(626 \mathrm{~mm}$, year to year). ET of mountainous vegetation was stable around $600 \mathrm{~mm}$ and the inter-annual variation of ET was mainly caused by variation in P. Due to higher P, WY was positive in 2008 (9.121 mm), 2010 (58.614 mm), 2011 (142.46 mm) and 2012 (123.49 mm). On the contrary, WY was negative in the other 8 years, especially in 2002, 2003 and 2009 with severe water deficiency (WY < $150 \mathrm{~mm})$.

There are 20 large and medium-scale reservoirs in Beijing with a total area of $1595 \mathrm{~km}^{2}$ (Fig. 2). The mean annual P (544.62 mm) of catchment region for the 20 reservoirs was consistent with the mean annual $\mathrm{P}(550.38 \mathrm{~mm})$ of mountainous vegetation, and the mean annual ET (575.57 mm) was slightly lower than the mountainous vegetation $(600 \mathrm{~mm})$. During the years when WY was greater than zero (2008, 2010, 2011 and 2012), catchment region generated $35.74 \mathrm{~mm}, 79.30 \mathrm{~mm}, 132.35 \mathrm{~mm}$ and $118.95 \mathrm{~mm}$, respectively. Runoff merged into reservoirs, this was the equivalent of $57,126,211$ and 189 million $\mathrm{m}^{3}$ of water, which contributed 7.55 , $24.21,27.34$ and $56.46 \%$ of water to the total water inflow into the reservoirs. There was no runoff contributing to the reservoirs in the other 8 years when WY was negative, which indicating that the concentration rate was gradually decreasing with the climate changes. Fig. 6.

\subsubsection{Suburban farmland}

Average annual P was approximately $538.26 \mathrm{~mm}$ for suburban farmland, which was slightly lower than that of the mountainous vegetation. Annual $P$ of suburban farmland showed large variability, the maximum occurred at $2012(733.20 \mathrm{~mm})$, while the minimum value was found at $2002(369.29 \mathrm{~mm})$. This was different from ET affected by $P$ for mountainous vegetation. The maximum ET was in 2002 that was $586 \mathrm{~mm}$, and P was the smallest during the study period. ET of suburban farmland remained stable from 2005 to 2007, while the P in $2006(387.17 \mathrm{~mm}$ ) was lower in 2005 $(503.4 \mathrm{~mm})$ than $2007(520.0 \mathrm{~mm})$. The WY fluctuation originated from the differences between P and ET. Six years (2005, 2007, 2008, 2010, 2011, and 2012) yielded a water surplus with the highest

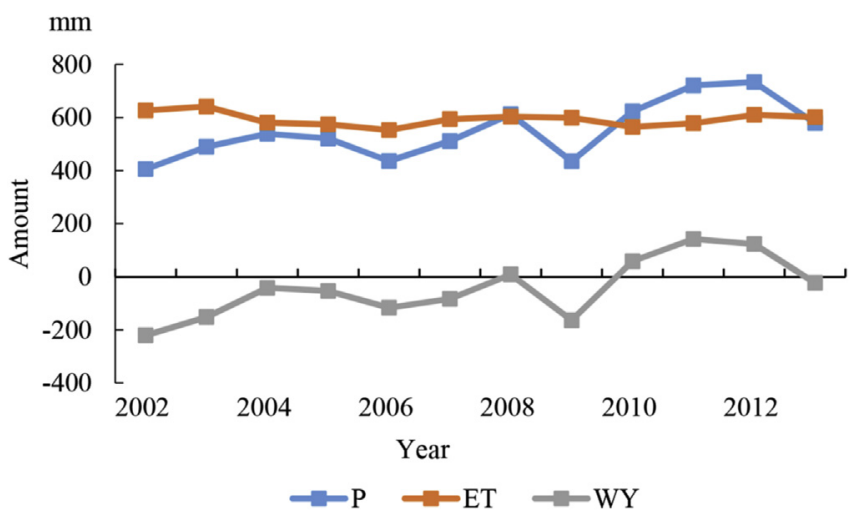

Fig. 6. The temporal changes in P, ET and WY of Mountainous vegetation in Beijing from 2002 to 2013

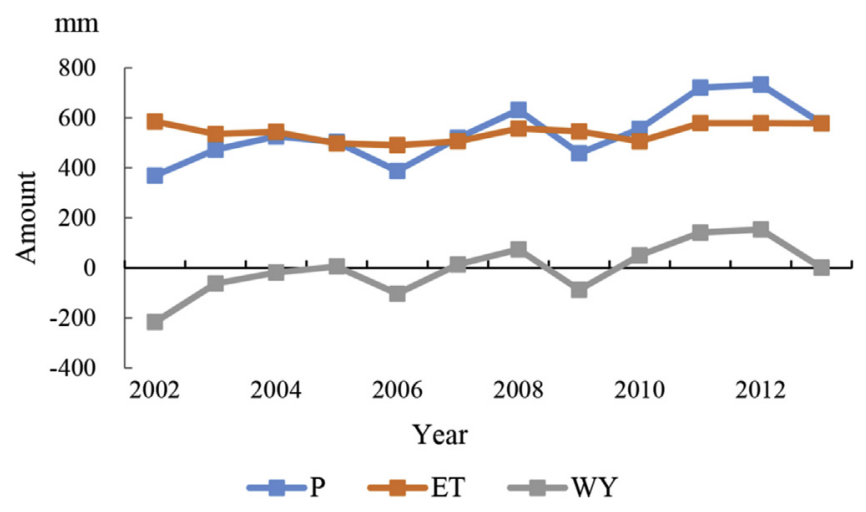

Fig. 7. The temporal changes in P, ET and WY of suburban farmland in Beijing from 2002 to 2013.

occurring in $2012(\mathrm{WY}=154.04 \mathrm{~mm})$, while the other years were water deficient. The extra water for ET came from irrigation. Fig. 7.

The feature of decentralized management in suburban farmland causes the ET may have large variation within small spatial range, so we chose remote sensing data of $30 \mathrm{~m}$ resolution to study the irrigation efficiency for suburban farmland. Meanwhile, the 2005 and 2006 was normal year and dry year respectively, which can help to analyze the issue of irrigation efficiency through comparing the situation of ET and AI in different rainfall years. Therefore, we used five counties and two years of data as examples to illustrate the irrigation efficiency for suburban farmland (Table 1). High water-consumption (ET $>600 \mathrm{~mm}$ ) area was spread over all districts, the area of high water-consumption was $238.81 \mathrm{~km}^{2}$ in 2005 and $225.243 \mathrm{~km}^{2}$ in 2006 . The maximum area of high waterconsumption farmland occurred in Tongzhou (120.00 $\left.\mathrm{km}^{2}\right)$, which accounted for $50 \%$ of the total area of high water-consuming farmland in five counties. The distribution of high consumption farmland was scattered and the areas were relatively small in the other four districts. From Table 1, we can see that the ET maintained stability in each district/country from 2005 to 2006. The difference of P caused the clear distinction of WD in the two years. In 2005, the WD was equal to 0 in each district/country due to the $P$ higher than the ET, while the AI was as high as $115 \mathrm{~mm} / \mathrm{m}^{2}$. Meanwhile, the ET had no significant difference in 2005, while the P obviously less than the value in 2005. The WD was higher than 0 in four districts/ country (Daxing, Fangshan, Tongzhou and Pinggu). Comparing the WD and AI in 2006, we found that the AI could effectively compensate for the $\mathrm{WD}$, the highest $\mathrm{AI}$ utilization occurred at Tongzhou. However, the value of AI was more than the WD in Daxing, Fangshan, Miyun and Pinggu, indicating the AI has not been effective use. As such, suburban farmland could be considered water waste.

Table 1

ET and AI of suburban farmland in Beijing in 2005 and 2006.

\begin{tabular}{lllllll}
\hline Year & District/Country & $\mathrm{CA}\left(\mathrm{m}^{2}\right)$ & $\mathrm{P}(\mathrm{mm})$ & $\mathrm{ET}(\mathrm{mm})$ & $\mathrm{WD}(\mathrm{mm})$ & $\mathrm{AI}(\mathrm{mm})$ \\
\hline 2005 & Daxing & 385733000 & 508.45 & 476.12 & 0 & 115 \\
& Fangshan & 282172000 & 476.43 & 423.12 & 0 & 115 \\
& Miyun & 222322000 & 495.89 & 424.98 & 0 & 115 \\
& Pinggu & 115553000 & 531.82 & 483.32 & 0 & 115 \\
& Tongzhou & 361120000 & 526.09 & 522.89 & 0 & 115 \\
\hline 2006 & Daxing & 382460000 & 383.08 & 485.22 & 101.13 & 120 \\
& Fangshan & 279759000 & 356.79 & 442.89 & 86.10 & 120 \\
& Miyun & 223663000 & 410.51 & 365.63 & 0 & 120 \\
& Pinggu & 118708000 & 411.83 & 492.75 & 80.928 & 120 \\
& Tongzhou & 358090000 & 395.60 & 533.55 & 139.952 & 120 \\
\hline
\end{tabular}




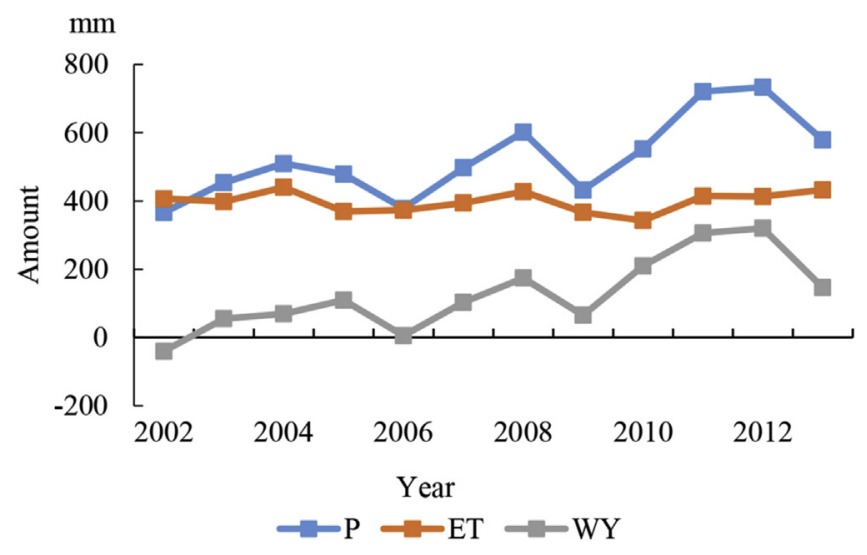

Fig. 8. The temporal changes in P, ET and WY of green gardens in Beijing from 2002 to 2013. (For interpretation of the references to colour in this figure legend, the reader is referred to the web version of this article.)

\subsubsection{Green gardens}

The average annual $\mathrm{P}$ was $525.14 \mathrm{~mm}$ for green gardens from 2002 to 2013, which were smaller than that of mountainous vegetation and suburban farmland. The inter-annual $P$ was relatively high with the maximum occurring in $2012(733.20 \mathrm{~mm})$ and the minimum in 2002 (366.29 mm). ET was relatively consistent $(400 \mathrm{~mm})$ among the years. WY in the green gardens was much higher compared to natural vegetation and farmland, indicating that the green garden was in water surplus with the exception of 2002. Fig. 8.

Specifically, we used the data for six parks in three years with different rainfall patterns, which includes the dry year (2009), the moderate year (2013) and the wet year (2012), to illustrate the irrigation efficiency of the green gardens. As shown in Table 2, the area of the green gardens was comparatively small, of which the maximum area was the Olympic Forest Park $\left(2.7 \mathrm{~km}^{2}\right)$. The difference of $P$ was smaller in each park, while the ET of each park was obviously different, and the maximum ET was in the Xiangshan Park (700.88 mm, $684.5 \mathrm{~mm}$ and $672.4 \mathrm{~mm}$ ). Based on the field investigation, we found that the irrigation was identical in each year. In the year of 2009 and 2010, there were 4 parks where the WD was equal to 0 because the P was larger than ET, while the AI was as high as $581.95 \mathrm{~mm} / \mathrm{m}^{2}$. The mean WD of Beijing Botanical Garden and Xiangshan Park was $245.76 \mathrm{~mm}$ and $69.42 \mathrm{~mm}$ in 2009 and 2013, the AI could compensate for the WD. However, the AI was 2.24 times and 7.95 times higher than WD in the two parks.

\section{Discussions}

\subsection{Mountainous vegetation and its water resources effects}

Mountainous vegetation can play a part in the regulating function of surface runoff through ET and soil water storage (Ouyang,
2004; Tratalos et al., 2007; Xu et al., 2011; Yang et al., 2015), which consequently reduces overland runoff (Tratalos et al., 2007; López-Moreno et al., 2008; Ristić et al., 2011; Huang et al., 2012). Natural ecological systems keep water balance over the long term, and our data showed that ET had changed to be balanced with longterm $\mathrm{P}$ for mountainous vegetation. Through comparing the ET (resolution: $1 \mathrm{~km}$ ) and $\mathrm{P}$ (resolution: $1 \mathrm{~km}$ ), we found that $\mathrm{P}$ was mostly used by vegetation in normal years. In years of large rainfall, mountainous vegetation can prevent the soil erosion by regulating surface runoff (from 2010 to 2012).

Increasing water resources became an urgent problem with the rapid increase of water demand, thus the function of water supplement to the reservoirs from mountainous vegetation in catchment region has attracted interests (Hornbeck et al., 1993; Kumagai et al., 2014). Although many water transfer projects provided water resources for Beijing, improving the water reserves is a basic way to release the water stress. During the study period, the year 2011 and 2012 experienced larger amounts of rainfall (about 211 million $\mathrm{m}^{3}$ and 311 million $\mathrm{m}^{3}$ ) which can supply water for the reservoirs, and the contribution rate was $27.34 \%$ and $53.46 \%$.

\subsection{Suburban farmland and its water resources effects}

Irrational irrigation may lead to high ET and serious water waste in farmland (Huang et al., 2012; Wang et al., 2015b; Wang et al., 2016). The traditional idea "the more irrigation water and fertilizer we input, the higher farmland income we will get" leads to sharp decline of the underground water level and unsustainable utilization of water resource in the region of agricultural land (Huang et al., 2012; Qi et al., 2013; Lin et al., 2013). Based on the ET data (resolution: $1 \mathrm{~km}$ ) and P data (resolution: $1 \mathrm{~km}$ ), our study found that the water yield of suburban farmland was less affected by rainfall, and the difference of ET was mainly caused by artificial irrigation. For example, maximum ET (586 mm) occurred in 2002, while the $\mathrm{P}(387 \mathrm{~mm})$ was the minimum during the study period. Comparing ET (resolution: $30 \mathrm{~m}$ ) and the amount of actual irrigation in 2005 to that in 2006 among five districts, we found that there was a significant difference in the WD between the two years, which was $0 \mathrm{~mm}$ in 2005 while $81.56 \mathrm{~mm}$ in 2006. However, AI remained as high as $115 \mathrm{~mm} / \mathrm{m}^{2}$ in the two years. Meanwhile, the higher water consumption farmland areas were nearly $230 \mathrm{~km}^{2}$ in the five districts, in which 7.58 million $\mathrm{m}^{3}$ of water can be considered as irrational irrigation. The irrational irrigation causes the extremely common of water waste, so we should adjust the irrigation amount according to the climate (Zhu et al., 2012; Kono et al., 2012; Deng and Zhao, 2015).

\subsection{Green gardens and its water resources effects}

Water waste is extremely common in green gardens, which is caused by lower natural rainfall utilization and excessive irrigation.

Table 2

The ET and AI of Beijing's green gardens in 2009,2012 and 2013.

\begin{tabular}{|c|c|c|c|c|c|c|}
\hline Park & Olympic forest park & Beijing botanical garden & Taoranting park & Beijing zoo & Zizhuyuan park & Xiangshan park \\
\hline $\mathrm{CA}\left(\mathrm{m}^{2}\right)$ & 2700000 & 1259000 & 320000 & 419000 & 450000 & 1600000 \\
\hline P2009 (mm) & 432.32 & 434.06 & 405.18 & 441.57 & 440.54 & 451.52 \\
\hline ET2009 (mm) & 397.2 & 676.17 & 85 & 125 & 141 & 700.88 \\
\hline WD2009 (mm) & 0 & 242.11 & 0 & 0 & 0 & 249.36 \\
\hline P2012 (mm) & 733.2 & 733.2 & 733.2 & 733.2 & 733.2 & 733.2 \\
\hline ET2012 (mm) & 494.6 & 657.17 & 105 & 226 & 226 & 684.5 \\
\hline WD2012 (mm) & 0 & 0 & 0 & 0 & 0 & 0 \\
\hline P2013 (mm) & 578.2 & 578.2 & 578.2 & 578.2 & 578.2 & 578.2 \\
\hline ET2013 (mm) & 516.5 & 622.8 & 141 & 210 & 183 & 672.4 \\
\hline WD2013 (mm) & 0 & 44.63 & 0 & 0 & 0 & 94.2 \\
\hline $\mathrm{AI}(\mathrm{mm})$ & 120.37 & 603.28 & 1247.66 & 715.31 & 244.44 & 499.99 \\
\hline
\end{tabular}


During the study period, ET of the green gardens were consistently maintained at $400 \mathrm{~mm}$, which were obviously enough for the normal growth with the mean annual P of $474.73 \mathrm{~mm}$. However, the area of green gardens were too small and the urban surface is too impervious so that it is difficult to utilize natural rainfall effectively in the center city. Therefore, we should build rainfall collecting system realizing the smartly stored of rainfall water and the more rainfall water can be used in the process of irrigation (Tokar and Markus, 2000; Arneborg, 2005; Chen et al., 2013). Meanwhile, unreasonable water management mechanisms and the inefficient irrigation methods also cause water waste problem in green gardens (Zhang et al., 2012a,b). AI of the six large urban parks was $581.95 \mathrm{~mm} / \mathrm{m}^{2}$, which was far beyond its ET (390.9 mm). However, the irrigation amount in Olympic Forest Park is significantly lower than other parks because the utilization ratio of intelligent irrigation technology was more than other parks, which indicates that the intelligent irrigation is very useful for saving water in green gardens.

\subsection{The comparison with three types green spaces water resources effects}

The different types of green space have difference effects on water resources. The mountainous vegetation has the positive effects on the water resources, while the inefficient irrigation of suburban farmland and green gardens lead to the negative impacts on water resources (Ouyang, 2004; Tratalos et al., 2007; Xu et al., 2011). The mountainous vegetation maintained normal growth through the self-adjustment although it remained the water deficiency during the study period, and it can supply water to the reservoirs. Although the mean ET of suburban farmland and green gardens was significantly lower than the mountainous vegetation, they cannot efficient use the rainfall water because the water leaves fast in the impervious surfaces. Meanwhile, the excessive irrigation in the suburban farmland and green gardens also caused the water shortage and groundwater level decline even the $\mathrm{P}$ of Beijing $(578 \mathrm{~mm}$ ) is not lower than other regions (Pfeiffer and Lin, 2014).

The lower ratio of green gardens in urban center area leads to the lower ability of surface runoff regulation, which will add up to the possibility of waterlogging. Our data shown that the rainfall spatial distribution have not obvious differences, the difference of ET capacity may be the primary cause of the regional distribution of WY. The areas of artificial surfaces were significantly more than green gardens (Fig. 3), and whose ET was lower than green space (Fig. 5). Therefore, the fragment green gardens cannot play the function of surface runoff regulation, and large amount of natural rainfall in urban center turns into ineffective overland runoff and enter into urban sewerage system, causing the significant water waste (Friedman et al., 1995). When extreme precipitation occurs, urban sewerage system become blocked and cause city waterlogging (Yin et al., 2011; Zhang et al., 2012a,b). A notable case occurred on July 21, 2012, where $164 \mathrm{~mm} / \mathrm{d}$ of rainfall caused severe waterlogging and contributed to the deaths of 77 people leading to huge economic losses to society.

\subsection{The integrated management scheme of water resources of green space}

The decreasing precipitation aggravates water shortage, which has seriously restricted the urban development (Liu and Deng, 2011; Huang et al., 2012). During the study period, the water consumption has exceeded $35^{*} 10^{8} \mathrm{~m}^{3}$ while the water resource was below $25^{*} 10^{8} \mathrm{~m}^{3}$ in Beijing, which indicating the groundwater consumption was high (Fig. 9). However, irrational irrigation of suburban farmland and green gardens were still widespread, which

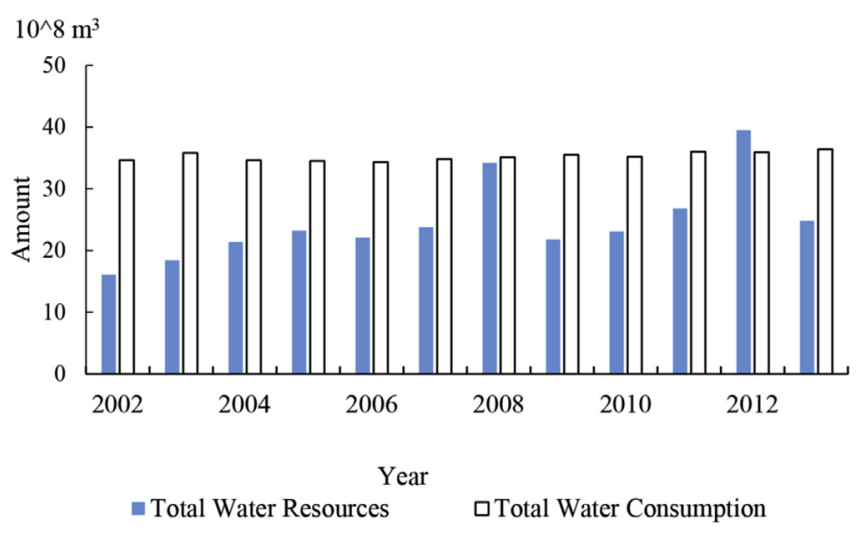

Fig. 9. Total water resources and water consumption in Beijing from 2002 to 2013.

aggravated the water shortage and easily caused the land subsidence. With the implementation of the 13th Five-Year Plan and the further construction of ecological civilization, the scale of Beijing's green space will show an upward trend (Deng et al., 2008, 2010; Wang et al., 2015a). Hence, building integrated water management scheme for green space is an urgent task (Marlow et al., 2013).

Integrated water management scheme of Beijing's green space should take mountainous vegetation, suburban farmland and green gardens into account (Deng and Zhao, 2015). First of all, the carrying capacity of ecological water resources should consider in the process of vegetation breeding and crop cultivation. Secondly, the irrigation may be reduced through the construction of natural hydrologic cycle in green space and the improvement of rainfall utilization. Lastly, the water management level of green space may improve through constructing unified water management department.

Reasonable vegetation breeding and crop cultivation are the foundation of effective water utilization. Although the area of mountainous forest was increased in the past ten years, many researchers found that the water supplement was gradually decreased with unreasonable development of woodland (Zhang et al., 2009). Thus, the water consumption of vegetation and the carrying capacity of ecological water resources should be fully considered during the process of afforestation, which may impact the water supplement of catchment region (Tratalos et al., 2007). Meanwhile, the indigenous species ratio and the structural integrity of vegetation should require highest attention. The widely distributed higher water consumption farmland cause severe water-wasting in suburban farmland. Therefore, we should avoid cultivating high water consumption crops such as wheat, cotton, and lotus (Wang et al., 2016). During the development of green gardens, the appreciation of aesthetically pleasing vegetation is the primary factor, but researchers have shown that generally more aesthetically pleasing vegetation often requires more water consumption. Hence, we should consider water consumption of vegetation and not blindly just purses aesthetics for the development of green gardens, the ET of tree species should not exceed than $500 \mathrm{~mm}$ (Kabisch et al., 2016).

Reconstructive natural hydrologic cycle in urban green space may help to reduce irrigation (Pataki et al., 2011). Our results showed that mountainous vegetation could grow normally without irrigation. So depending on the natural hydrologic cycle, the irrigation also can reduce in suburban farmland and green gardens. Therefore, we should properly develop farmland and green gardens in the junction of mountain and plain, which may help the vegetation adequately absorb the mountainous runoff for the growth. Moreover, the construction of urban green network is also an 
important approach to reconstruct natural hydrologic cycle. Construction of green way with the width of $10 \mathrm{~m}-30 \mathrm{~m}$ along the six major river would strengthen the connection between mountainous vegetation and green gardens, and effectively utilize river water to irrigate.

Improving the rainfall utilization can efficiently reduce the irrigation and the occurrence of waterlogging in metropolis areas. Firstly, through construction of the sponge city may improve the rainfall utilization in green gardens. Beijing should gradually expand the pervious pavement area and the scale of green gardens in the central region, and moderately increase the ratio of sunken green space. Secondly, rain-harvesting systems should be constructed in each park and irrigation area, which may help to improve rainfall utilization and reduce the demand for groundwater (Wong, 2007; Coutts et al., 2012).

During the field investigation, we found that different water management level makes difference for irrigation efficiency. Thus, unified water management department for green spaces needs to be established. Firstly, the department should responsible for popularizing the advanced irrigation methods in suburban farmland and green gardens, such as movable sprinklers and pointer sprinklers (Whittlesey, 2003; Elliotta and Deryng, 2014). Secondly, the department also need regulate the irrigation amount according to meteorological forecasts (Kumar et al., 2002; Pulido-Calvo et al., 2003; Kumagai et al., 2014). In the wet year ( $P \geq 650 \mathrm{~mm})$ and the moderate year $(650 \mathrm{~mm} \geq \mathrm{P} \geq 450 \mathrm{~mm})$, the irrigation amount should be lower than $50 \mathrm{~mm} / \mathrm{m}^{2}$ in case there is no rain in the long term. But, in the dry year ( $\mathrm{P} \leq 450 \mathrm{~mm})$, the irrigation amount should be lower than $150 \mathrm{~mm} / \mathrm{m}^{2}$ in farmland and the amount should be no more than $200 \mathrm{~mm} / \mathrm{m}^{2}$ in green gardens. Third, the department should promote the development of agriculture sightseeing gardens, which can help construct rain-harvesting systems (Bjornlund et al., 2009).

\section{Conclusion}

In conjunction with remote sensing, actual investigation and statistical data, this paper studied the spatial-temporal variation of water balance in Beijing's green space from 2002 to 2013. The results showed that the positive water yield of mountainous vegetation and suburban farmland caused the water deficiency in suburban region, and the positive water yield of green gardens and artificial surfaces made the water surplus in urban central areas. However, the water surplus state easily causes issues such as water waste and urban waterlogging becoming more severe. Different types of green space have obvious differences in water use and impacts on water resources. Mountainous vegetation can fully utilize the rainfall to grow without irrigation, regulate the surface runoff and supply water to reservoirs. Unreasonable irrigation in suburban farmland and green gardens cause negative impacts for water resources. The lower efficiency of natural rainfall and inefficient irrigation lead to serious waste of water resources in farmland and green gardens. Therefore, designing effective water management for urban green space requires full consideration of the actual water use and its impact on water resources for different types of green space. This paper proposed the integrated management scheme based on the overall planning, which includes reasonable choice of plant species, reconstruction of natural hydrologic cycle, improving the rainfall utilization ratio, and constructing unified management department. Through the integrated water management in green space, the positive effects of mountainous vegetation will be better achieved and the natural rainfall utilization will improve in suburban farmland and green gardens, which may help to alleviate the water security crisis of the capital region.

\section{Acknowledgements}

Financial support for this research was provided by the Project of Social Science Youth Foundation of Beijing Municipal (Grant No. 15JGC148), the Project of the General Program of National Social Science Foundation of China (Grant No. 15BGL130), and the Project of Humanity and Social Science Youth Foundation of Education Ministry of China (Grant No. 13YCZH131). Feng Mi, Xuanchang Zhang and Nan Lu conceptualized the article, conducted background research, and edited the content. Nana Yan provided the ETWatch data and edited the content. Shibao Yuan and Qiang Peng gathered the irrigation data of green garden in field investigation. Lenka Kuglerova and Oliver Zheyi Ma also adjusted the structure and polished the language.

\section{References}

Arneborg, J., 2005. Greenland Irrigation Systems on a West Nordic Background: an Overview of the Evidence of Irrigation Systems in Norse Greenland C, pp. 980-1450 (AD).

Barthel, S., Isendahl, C., 2013. Urban gardens, agriculture, and water management: sources of resilience for long-term food security in cities. Ecol. Econ. 86, $224-234$.

Bjornlund, H., Nicol, L., Klein, K.K., 2009. The adoption of improved irrigation technology and management practices-a study of two irrigation districts in Alberta, Canada. Agr. Water Manage 96 (1), 121-131.

Bosch, J.M., Hewlett, J.D., 1982. A review of catchment experiments to determine the effect of vegetation changes on water yield and evapotranspiration. J. Hydrol. 55 (1), 3-23.

Brown, R.R., Farrelly, M.A., Loorbach, D.A., 2013. Actors working the institutions in sustainability transitions: the case of Melbourne's stormwater management. Glob. Environ. Change 4 (23), 701-718.

Byomkesh, T., Nakagoshi, N., Dewan, A.M., 2012. Urbanization and green space dynamics in Greater Dhaka, Bangladesh. Landsc. Ecol. Eng. 8 (1), 45-58.

Chen, W., Lu, S., Pan, N., Jiao, W., 2013. Impacts of long-term reclaimed water irrigation on soil salinity accumulation in urban green land in Beijing. Water Resour. Res. 49 (11), 7401-7410.

Colding, J., Barthel, S., 2013. The potential of 'Urban Green Commons' in the resilience building of cities. Ecol. Econ. 86, 156-166.

Coutts, A.M., Tapper, N.J., Beringer, J., Loughnan, M., Demuzere, M., 2012. Watering our cities: the capacity for water sensitive urban design to support urban cooling and improve human thermal comfort in the Australian context. Prog. Phys. Geog 12-16.

Deng, X., Huang, J., Rozelle, S., Uchida, E., 2008. Growth, population and industrialization, and urban land expansion of China. J. Urban Econ. 63 (1), 96-115.

Deng, X., Huang, J., Rozelle, S., Uchida, E., 2010. Economic growth and the expansion of urban land in China. Urban Stud. 47 (4), 813-843.

Deng, X., Zhao, C., 2015. Identification of water scarcity and providing solutions for adapting to climate changes in the Heihe River Basin of China. Adv. Meteorol. 2015.

Diane, P.E., Margaret, M.C., Jennifer, C., Cherrier, J., Grulke, N.E., Jennings, V., Pincetl, S., Zipperer, W.C., 2011. Coupling biogeochemical cycles in urban environments: ecosystem services, green solutions, and misconceptions. Front. Ecol. Environ. 9 (1), 27-36.

Dobbie, M.F., Brookes, K.L., Brown, R.R., 2014. Transition to a water-cycle city: risk perceptions and receptivity of Australian urban water practitioners. Urban Water J. (6), 427-443.

Elliotta, J., Deryng, D., 2014. Constraints and potentials of future irrigation water availability on agricultural production under climate change. Pnas 9 (111), 3239-3244.

Fan, L., Wang, H., Lai, W., Wang, C., 2015. Administration of water resources in Beijing: problems and countermeasures. Water Policy 17 (4), 563-580.

Farley, K.A., Jobbágy, E.G., Jackson, R.B., 2005. Effects of afforestation on water yield: a global synthesis with implications for policy. Glob. Change Biol. 11 (10), 1565-1576.

Friedman, J.M., Scott, M.L., Lewis Jr., W.M., 1995. Restoration of riparian forest using irrigation, artificial disturbance, and natural seedfall. Environ. Manage 19 (4), $547-557$.

Gill, S.E., Handley, J.F., 2007. Adapting cities for climate change: the role of the green infrastructure. Built Environ. 1 (33), 115-133.

Hornbeck, J.W., Adams, M.B., Corbett, E.S., Verry, E.S., Lynch, J.A., 1993. Long-term impacts of forest treatments on water yield: a summary for northeastern USA. J. Hydrol. 150 (2), 323-344.

Huang, J., Zhang, H., Tong, W., Chen, F., 2012. The impact of local crops consumption on the water resources in Beijing. J. Clean. Prod. (21), 45-50.

Kabisch, N., Strohbach, M., Haase, D., Kronenberg, J., 2016. Urban green space availability in European cities. Ecol. Indic. (70), 586-596.

Kong, F., Yin, H., Nakagoshi, N., Zong, Y., 2010. Urban green space network development for biodiversity conservation: identification based on graph theory and gravity modeling. Landsc. Urban Plan. 95 (1), 16-27. 
Kono, S., Ounvichit, T., Ishii, A., Satoh, M., 2012. Participatory system for water management in the toyogawa irrigation project, Japan. Paddy Water Environ. 10 (1), 75-81.

Kumagai, T.O., Tateishi, M., Miyazawa, Y., Kobayashi, M., Yoshifuji, N., Komatsu, H., Shimizu, T., 2014. Estimation of annual forest evapotranspiration from a coniferous plantation watershed in Japan (1): water use components in Japanese cedar stands. J. Hydrol. 508, 66-76.

Kumar, M., Raghuwanshi, N.S., Singh, R., Wallender, W.W., Pruitt, W.O., 2002. Estimating evapotranspiration using artificial neural network. J. Irrig. Drain. Eng. 128 (4), 224-233.

Lee, A.C., Maheswaran, R., 2011. The health benefits of urban green spaces: a review of the evidence. J. Public Health-UK 33 (2), 212-222.

Li, L., Zhang, L., Xia, J., Gippel, C.J., Wang, R., Zeng, S., 2015. Implications of modelled climate and land cover changes on runoff in the middle route of the south to north water transfer project in China. Water Resour. Manag. 29 (8), 2563-2579.

Lin, Y., Deng, X., Jin, O., 2013. Economic effects of drought on agriculture in North China. Int. J. Disaster Risk Sci. 4 (2), 59-67.

Liu, J., Deng, X., 2011. Influence of different land use on urban microenvironment in Beijing City, China. J. Food, Agric. Environ. 9 (3-4), 1005-1011.

López-Moreno, J.I., Beniston, M., García-Ruiz, J.M., 2008. Environmental change and water management in the Pyrenees: facts and future perspectives for Mediterranean mountains. Glob. Planet Change (61), 300-312.

Lu, N., Chen, S., Wilske, B., Sun, G., Chen, J., 2011. Evapotranspiration and soil water relationships in a range of disturbed and undisturbed ecosystems in the semiarid Inner Mongolia, China. J. Plant Ecol. 4 (1-2), 49-60.

Marlow, D.R., Moglia, M., Cook, S., Beale, D.J., 2013. Towards sustainable urban water management: a critical reassessment. Water Res. 47 (20), 7150-7161.

Ouyang, Li, 2004. The structure and ecological function of greenbelt in mega-city. City Plan. Rev. 4 (28), 41-45.

Pataki, D.E., Carreiro, M.M., Cherrier, J., Grulke, N.E., Jennings, V., Pincetl, S. Pouyat, R.V., Whitlow, T.H., Zipperer, W.C., 2011. Coupling biogeochemical cycles in urban environments: ecosystem services, green solutions, and misconceptions. Front. Ecol. Environ. 9 (1), 27-36.

Pfeiffer, L., Lin, C.C., 2014. Does efficient irrigation technology lead to reduced groundwater extraction? Empirical evidence. J. Environ. Econ. Manag. 67 (2), 189-208.

Pulido-Calvo, I., Roldán, J., López-Luque, R., Gutiérrez-Estrada, J.C., 2003. Demand forecasting for irrigation water distribution systems. J. Irrig. Drain. Eng. 129 (6), $422-431$.

Qi, F., Wei, L., Haiyang, X., 2013. Comprehensive evaluation and indicator system of land desertification in the Heihe River Basin. Nat. Hazards 65 (3), 1573-1588.

Ristić, R., Radić, B., Vasiljević, N., Nikić, Z., 2011. Land use change for flood protection - a prospective study for the restoration of the river jelašnica watershed. Bull. Fac. For. (103), 115-130.

Tokar, A.S., Markus, M., 2000. Precipitation-runoff modeling using artificial neural networks and conceptual models. J. Hydrol. Eng. 5 (2), 156-161.

Tratalos, J., Fuller, R.A., Warren, P.H., Davies, R.G., Gaston, K.J., 2007. Urban form, biodiversity potential and ecosystem services. Landsc. Urban Plan. (83), $308-317$.

Tzoulas, K., Korpela, K., Venn, S., Yli-Pelkonen, V., Kaźmierczak, A., Niemela, J., James, P., 2007. Promoting ecosystem and human health in urban areas using Green Infrastructure: a literature review,. Landsc. Urban Plan. 81 (3), 167-178.

Wang, G., Chen, J., Deng, X., 2016. Modelling analysis of forestry input-output elasticity in China. Int. J. For. Res. 2016.
Wang, Z., Huang, K., Yang, S., Yu, Y., 2013. An input-output approach to evaluate the water footprint and virtual water trade of Beijing, China. J. Clean. Prod. 42, $172-179$.

Wang, Z., Yang, J., Deng, X., Lan, X., 2015a. Optimal water resources allocation under the constraint of land use in the Heihe River Basin of China. Sustainability-Basel 7 (2), 1558-1575.

Wang, X., Yang, H., Shi, M., Zhou, D., Zhang, Z., 2015b. Managing stakeholders conflicts for water reallocation from agriculture to industry in the Heihe river Basin in Northwest China. Sci. Total Environ. 505, 823-832.

Wang, E., Yu, Q., Wu, D., Xia, J., 2008. Climate, agricultural production and hydrological balance in the North China Plain. Int. J. Climatol 28 (14), 1959-1970.

Welch, J.M., 1993. Street and park trees of Boston: a comparison of urban forest structure. Landsc. Urban Plan. 2 (29), 131-143.

Whittlesey, N., 2003. Improving irrigation efficiency through technology adoption: when will it Conserve water? Dev. Water Sci. 50, 53-62.

Wolch, J.R., Byrne, J., Newell, J.P. 2014. Urban green space, public health, and environmental justice: the challenge of making cities 'just green enough'. Landsc. Urban Plan. 125, 234-244.

Wong, T.H.F., 2007. An overview of water sensitive urban design practices in Australia. Water Pract. Technol. 1 (1), 210-219.

Wu, B., Xiong, J., Yan, N., Yang, L., Du, X., 2008. ETWatch for monitoring regional evapotranspiration with remote sensing. Adv. Water Sci. 19 (5), 671-678.

Wu, B., Yan, N., Xiong, J., Bastiaanssen, W., Zhu, W., Stein, A., 2012. Validation of ETWatch using field measurements at diverse landscapes: a case study in Hai Basin of China. J. Hydrol. 436, 67-80.

Xia, J., Zhang, L., Liu, C., 2007. Towards better water security in North China. Water Resour. Manage (21), 233-247.

Xie, H., He, Y., Xie, X., 2017. Exploring the factors influencing ecological land change for China's Beijing-Tianjin-Hebei Region using big data. J. Clean. Prod. 142 677-687.

Xiong, J., Wu, B.F., Yan, N.N., Hu, M.G., Sun, M.Z., 2008. Research on temporal reconstruction of evapotranspiration using remote sensing. Prog. Geogr. 27 (2) 53-59.

Xu, X., Duan, X., Sun, H., 2011. Green space changes and planning in the capital region of China. Environ. Manag. (47), 456-467.

Yang, L., Zhang, L., Li, Y., Wu, S., 2015. Water-related ecosystem services provided by urban green space: a case study in Yixing City (China). Landsc. Urban Plan. (135), 40-51.

Yin, J., Xu, S., Wen, J., 2011. Community-based scenario modelling and disaster risk assessment of urban rainstorm waterlogging. J. Geogr. Sci. 21 (2), 274-284.

Zhang, B., Xie, G., Zhang, C., Zhang, J., 2012b. The economic benefits of rainwaterrunoff reduction by urban green spaces: a case study in Beijing, China. J. Environ. Manage (100), 65-71.

Zhang, B., Zhang, Z., LI, Y., 2009. Study on the selection and application of landscape tree species in Beijing, China. Landsc. Archit. 4, 31.

Zhang, X., Hu, M., Chen, G., Xu, Y., 2012a. Urban rainwater utilization and its role in mitigating urban waterlogging problems-a case study in Nanjing, China. Water Resour. Manag. 26 (13), 3757-3766.

Zhang, B., Wu, P., Zhao, X., Wang, Y., Gao, X., 2013. Changes in vegetation condition in areas with different gradients (1980-2010) on the Loess Plateau, China. Environ. Earth Sci. 68 (8), 2427-2438.

Zhu, W., Wang, S., Caldwell, C.D., 2012. Pathways of assessing agroecosystem health and agroecosystem management. Acta Ecol. sin. 32 (1), 9-17. 